\title{
REALIZATION OF AUTOMATED PRODUCTION ON CNC MILLING MACHINE
}

\section{B. Fecko, T. Vince}

Technical University of Košice

Letná, 9, Košice, 042 00, Slovak Republic. E-mail: branislav.fecko@tuke.sk, tibor.vince@tuke.sk

Purpose. Development the approach for creation the modularity of the Machinekit system that is used to control $\mathrm{CNC}$ automation in order to increase efficiency of its production due to automation of workpiece replacement, tool change and product assembly. Originality. The paper deals with the research on surveys for development of a low-cost prototype of $\mathrm{CNC}$ milling machine based on modular principle Methodology. The paper proposes one of the possibilities for development $\mathrm{CNC}$ milling machine using Beaglebone black low-cost development board. Authors described whole development process starting from computer simulation of developing device, hardware design, chose and calculation of power conversion elements, development of hardware unit, design and implementation low-level and high-level software solutions and also experimental verification of derived results. Results. We determine the effectiveness of systems based on the parameters required by the system. Features such as cost-effectiveness, simple repositioning, robustness, accuracy and reliability, and many others are mutually exclusive. Therefore, when designing automated systems, it is advisable to know well the input conditions and required system characteristics, and consequently the entire implementation of the system. Practical value. Advantage of automation is to increase production speed and eliminate the need for human intervention in production, thereby increasing accuracy and eliminating the possibility of errors that a human factor could entail in the process. The disadvantage of an automated system is the complex manufacturing configuration. Therefore, such systems achieve the greatest efficiency in mass production where there is no need for frequent system setup. References 10, figures 19.

Key words: CNC machine, automation, Axis, BeagleBone Black, Machinekit.

\section{РЕАЛІЗАЦІЯ АВТОМАТИЧНОЇ РОБОТИ ФРЕЗЕРНОГО ВЕРСТАТА 3 ЧИСЛОВИМ КЕРУВАННЯМ}

\section{Б. Фечко, Т. Вінсе}

Технічний університет Кошице

вул. Лєтня, 9, м. Кошице, 04200, Словаччина. E-mail: branislav.fecko@tuke.sk, tibor.vince@tuke.sk

В роботі наведено розробку підходів до створення модульного принципу створення автоматизованих машинних систем, що використовуються для систем 3 числовим програмним керуванням задля підвищення ефективності виробництва завдяки автоматизації зміни заготовки, зміни інструменту обробки та складання продукту. Наведено результати дослідження щодо розробки прототипу недорогої фрезерувальної машини 3 числовим керуванням на основі модульного принципу. Запропоновано одну з можливостей розробки фрезерувальної машини з числовим програмним керуванням з використанням недорогої плати розробника BeagleBone Black. Авторами наведено увесь процес розробки, починаючи від комп’ютерного моделювання розроблюваного пристрою, проектування апаратного забезпечення, вибору та розрахунку силових перетворювальних елементів, створення апаратного забезпечення, проектування й розробка програмного забезпечення нижнього і верхнього рівнів, а також експериментальна перевірка отриманих результатів. Підтверджено ефективність роботи системи на основі висунутих вимог. Такі чинники, як вартісна ефективність, простота перемонтування, робастність, точність й надійність, та багато інших, $є$ унікальними для даної розробки. Таким чином, при розробці автоматизованої системи доцільно знати точні вихідні умови та бажані характеристики системи. Перевагами автоматизації є підвищення швидкості виробництва та виключення участі людини у процесі виробництва, таким чином, підвищення точності та виключення можливості внесення помилок внаслідок людського фактору. Недоліком автоматизованої системи є складність конфігурування виробничого процесу. Таким чином, подібні системи набувають найбільшої ефективності при масовому виробництві, коли відсутня необхідність постійного переконфігурування системи.

Ключові слова: машина з числовим керуванням, автоматизація, вici, BeagleBone Black, Machinekit.

PROBLEM STATEMENT. Computer numerical control $(\mathrm{CNC})$ systems allow us to produce products more accurately and less costly. The next step to greater efficiency is to automate workpiece replacement, tool change, and product assembly. Our proposal examines the modularity of the Machinekit system that is used to control CNC automation.

EXPERIMENTAL PART AND RESULTS OBTAINED.

CNC milling machine
A $\mathrm{CNC}$ router is a computer controlled cutting machine. It consists of the machine construction, drilling machine and electronics. Construction of the machine is a device which allows milling head moving. Construction of the machine has to be strong and precise. Movements of the construction carry out stepper motors or servomotors. For the project are used stepper motors. We need special electronics and computers with appropriate software for controlling stepper motors. 


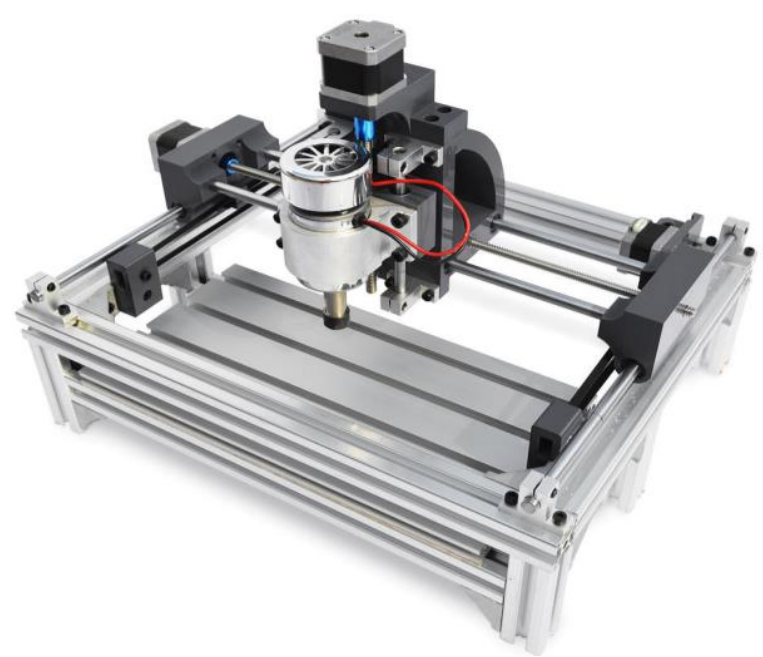

Figure 1 - CNC milling machine [1]

The machine construction must be appropriate to the application. It means, that by $\mathrm{CNC}$ system is possible milling for example the hard steel and soft wood too, but for maintaining efficiency the construction of machines will be different. The principles of controlling $\mathrm{CNC}$ systems remain the same. If you want create product by $\mathrm{CNC}$ machine, at first we have to create a 3D model of product. We do it with using CAD software. After that we use other software for generate G-code. This software is referred to as CAM software. CAM software can generate code for $\mathrm{CNC}$ router which is called G-code. Instructions for machine are inside G-code, they specify movement of machine. We move to this G-code in the computer which controls the machine and uses special software. This software controls the CNC machine with using the instructions from G-code. If we have everything ready on the machine we can run the program and machine starts to milling.

Next opportunity how create product by $\mathrm{CNC}$ is write G-code directly without usage CAM software.

$3 D$ design and realization of machine

Was created a 3D model of machine by software Pro/DESKTOP. This software formerly known as Design Wave, was a CAD program from Parametric Technology Corporation that allowed users to design and model in 3D and create 2D drawings. It can transfer a 3D design into a $2 \mathrm{D}$ engineering drawing format and also create photo-realistic views using Album Views. It is part-compatible with Pro/ENGINEER. We can see a 3D model of device in Figure 2.

First, we created a model of individual parts and then have them put together, to finish model. According to the 3D model, we started to produce individual parts and began building device.

Individual parts of the machine were made according to 3D design. Machining technologies such as cutting, milling, drilling, grinding were used to implement the proposed equipment. The functionality and accuracy of the implemented equipment is influenced by the quality and precision of its construction, therefore, during production, the precision and quality of the manufactured parts were taken into account.

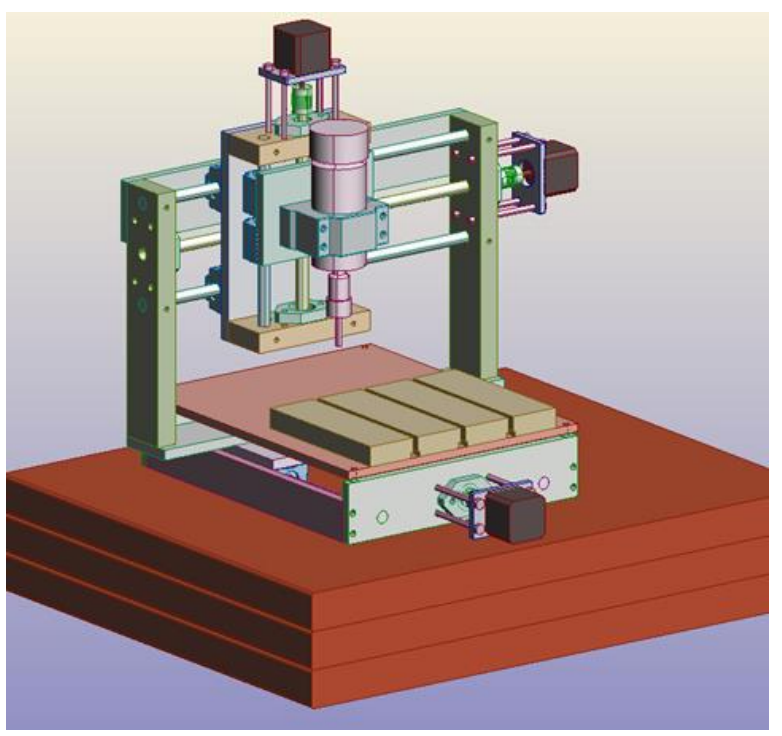

Figure 2-3D design of machine

After cutting the material and making the individual parts, the device was gradually folded. First, it was necessary to build the frame of the device and assemble the individual linear lines, connect the motors and pull the cabling. Following the calibration of individual axes and fixation of the device to the base. Figure 3 shows the implemented device. The construction was joined by screwing individual parts. 268 holes were drilled in the project and 54 were threaded. Dimensions of CNC milling machine with base are $50 \times 60 \times 57 \mathrm{~cm}$. The device, together with the base, weighs $39.5 \mathrm{Kg}$.

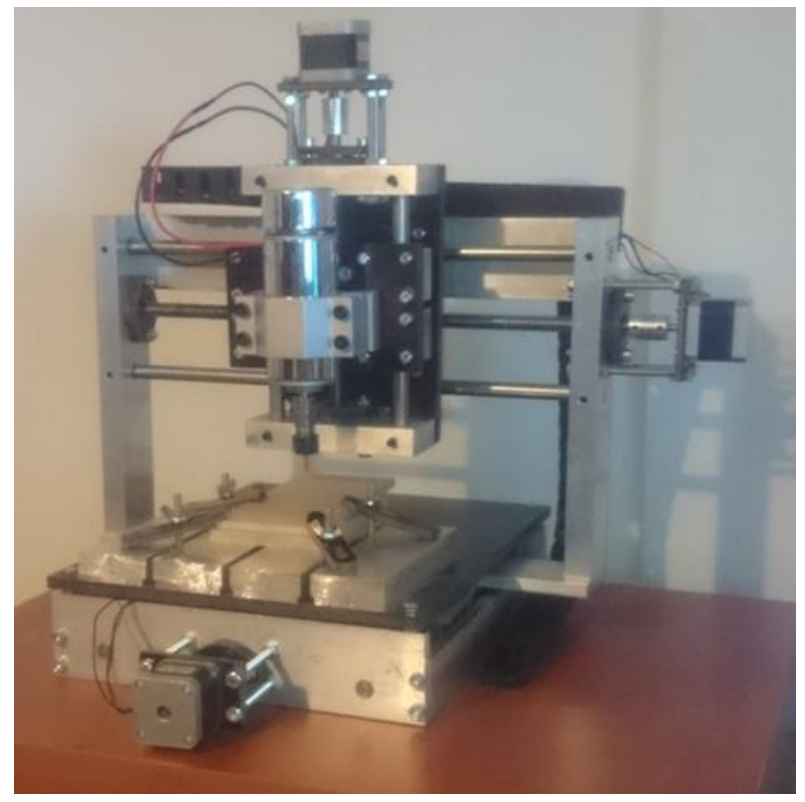

Figure 3 - Constructed the CNC milling machine 


\section{Control hardware of machine}

The main part of control system is the Beaglebone Black low-cost credit-card-sized development platform with good support from a fast growing community. It's similar to a Raspberry Pi. In Figure 4 we can see the Beaglebone Black.

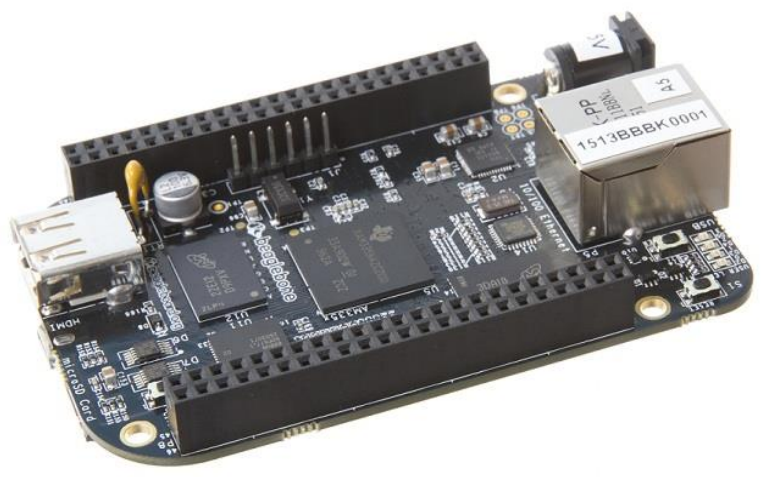

Figure 4 - BeagleBone Black

The basic features of the device are:

- AM3358 1GHz ARM® Cortex-A8 Processor;

- 4GB 8-bit eMMC Onboard Flash;

- 3D Graphics Accelerator;

- NEON Floating-Point Accelerator;

- 2x PRU 32-bit Microcontroller;

- USB Client for power and communications;

- USB Host;

- Ethernet;

- Micro HDMI;

- 2x 46-pin Headers.

The BeagleBone Black Processor includes two independent programmable units in real-time. A programmable real-time unit (PRU) is a fast (200-MHz, 32-bit) processor with single-cycle $\mathrm{I} / \mathrm{O}$ access to a number of the pins and full access to the internal memory and peripherals on the AM3358 processor on BeagleBone. They are design to provide softwaredefined peripherals as part of the Programmable Realtime Unit Industrial Control Subsystem and are capable of implementing things like 25 pulse-width modulators, 4 soft UARTs, stepper motor drivers and much more. Having these controllers integrated is really handy to avoid throwing in another device to control or interface to a new peripheral.

The BeagleBone hardware has been selected in the project because it has the most satisfactory properties at the lowest cost. It contains a staggering number of $\mathrm{I} / \mathrm{O}$ pins that I use to control each part of the device. The biggest advantage of BeagleBone hardware is the very good support of the Machinekit software and the great community of people who use this platform combinations in their projects.

Other essential components of the system are electronic components, including control electronics and actuators. Stepper motors was used for movement of axis and for spindle was used DC permanent magnet motor. To ensure proper control, the appropriate drivers for our engines had to be used.

Control software of machine

Machinekit (the Enhanced Machine Control) is a software system for computer control of machine tools such as milling machines and lathes, robots such as puma and scara and other computer controlled machines up to 9 axes. Machinekit is free software with open source code [1].

Machinekit provides:

- a graphical user interface (actually several interfaces to choose from);

- an interpreter for G-code (the RS-274 machine tool programming language);

- arealtime motion planning system with lookahead;

- operation of low-level machine electronics such as sensors and motor drives;

- an easy to use breadboard layer for quickly creating a unique configuration for your machine;

- a software PLC programmable with ladder diagrams.

A user interface is the part of the Machinekit that the machine tool operator interacts with. For the project were selected the standard GUI interface called the Axis. You can see the graphical interface in Figure 5.

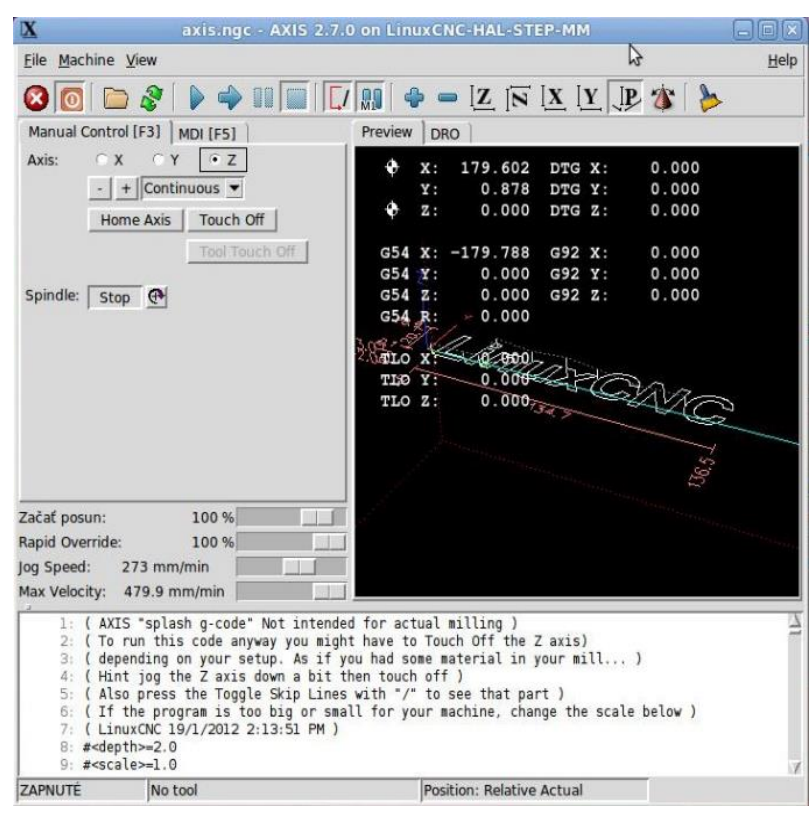

Figure 5 - Graphical inferface

After engaging the electronics and configuring the software we get the CNC machine, which work correctly. In the following section will be expanded to automate the production of products.

Automation of production

Expansion of the milling machine will be make the production of our products more efficient. To introduce automated continuous production system, it is necessary to solve the following problems: 
A. Storage and transport of the workpiece. It is necessary to store the workpiece correctly, and then in the right time to present the workpiece to the place where the workpiece is to be fixed and machined using the CNC milling machine. And after machining it is necessary to remove it to free the space of the next workpiece.

B. Attaching Workpieces. The gripping must be sufficiently strong to prevent the workpiece from slipping off, which would devalue the piece that would produce financial losses in the company. Furthermore, the clamping must be accurate to ensure the precision of the fabricated component with the associated production quality. Another dual factor in capture is the time of retention and repeatability of the process.

C. Machining the product. The product will be produced by milling. This process is realized by our CNC milling machine, which will be expanded.

D. Assembly of the product. Because the resulting product is a key ring with name of a web page of a department, you need to put on a circle for the assembled workpiece. And then the final product is produced, which is a turnkey pendant (Figure 6).

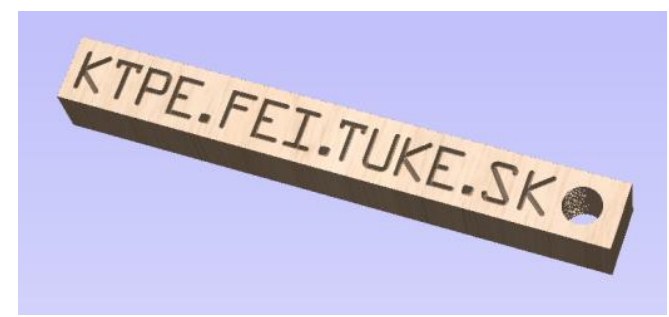

Figure 6 - Visualisation of product

\section{$3 D$ design of automation}

In Figure 2 we can see design of CNC machine. The model needs to be expanded by a part of automated production. It consists of automatic workpiece changes and assembly of finished parts. In Figure 7, you can see complete design of automation for continuous production.

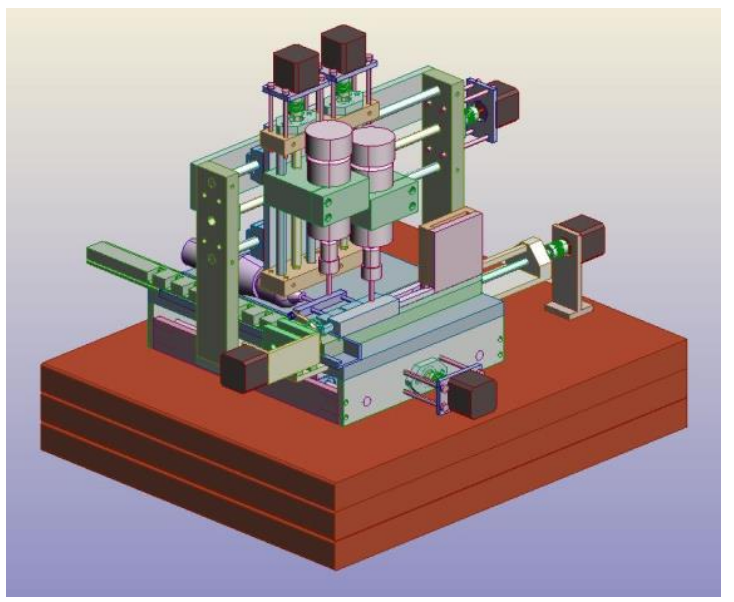

Figure 7 - 3D model of extended machine
Two milling tools are required to produce our components. One tool will be used to milling the inscription and the other is used to drill holes. Therefore we must to adjust our milling machine and extended it to another spindle. The advantage of this solution is the ability to automatically produce more kinds of products. We can see the extended milling head in Figure 8.

The workpieces needed to produce the products will be placed in the magazine. The capacity of the magazine is 10 pieces. The workpieces is inserted from the top into the magazine. In Figure 9 we can see a magazine that is highlighted in red.

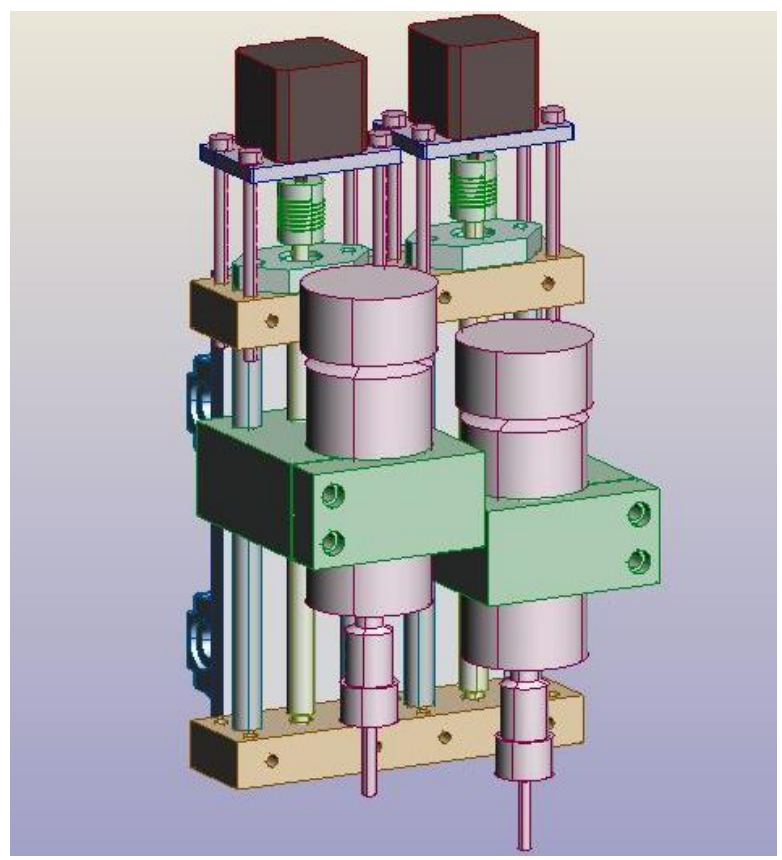

Figure 8 - Adding next the spindle

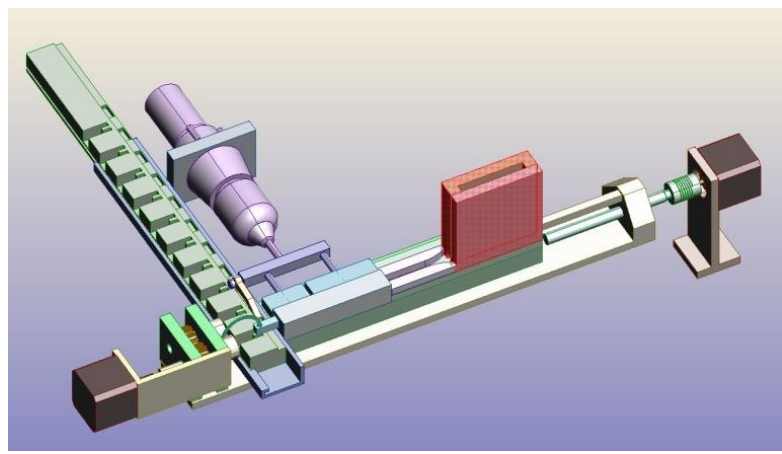

Figure 9-The magazine of workpieces

The workpiece is pulled out of the magazine by a sliding part. The sliding part consist of a rail where the workpiece is moved to the clamping portion. The feed is realized by a linear support. The movement is ensured by a threaded rod that is rotated by a stepping motor. In Figure 10, you can see the workpiece slider that is highlighted in red. 


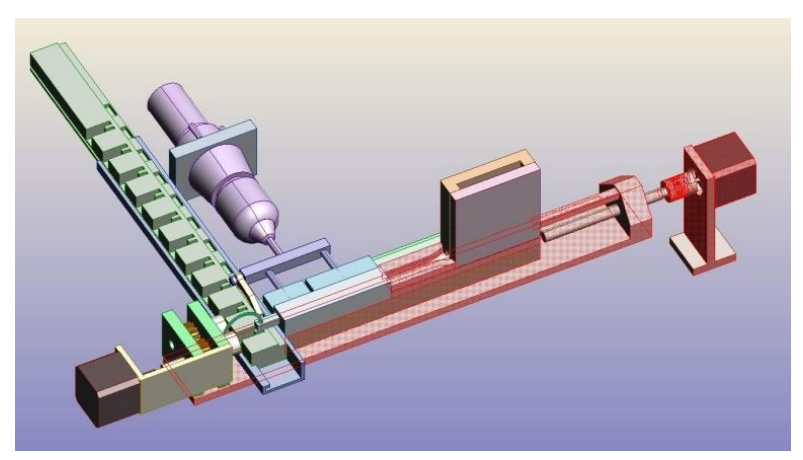

Figure 10 - The workpiece slider

We designed an automatic jaw vice for the workpiece grip. The gripper is able to adjust the clamping moment. Opening and closing of the jaw is ensured by a DC motor. After inserting the workpiece into the jaw vice, the vice automatically grip the component. After the workpiece has been correctly fastened, the milling machine performs the milling operations required for to produce the component. When the milling process is completed, the jaw vice is opened and moved to the next part of the vice. In the second part of the vice, the components are assembled. On Fig. 7, you can see the jaw vice that is highlighted in red.

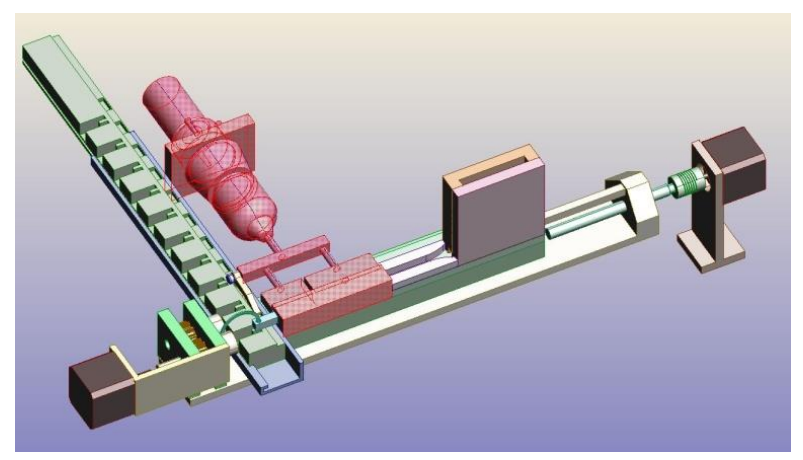

Figure 11 - The gripping device

The last part of the system is the assembly that automatically completes our workpiece and key circle. It is stored in the bin of the key circles, the key circles are placed in this bin, and the capacity is 10 pieces. The vice moves the bin in the forward direction, allowing the use of the next component from the bin. This bin is highlighted in red, shown in Figure 12.

In Figure 13 we can see the completion of the product. After being cut, the piece is moved to the second part of the jaw vice, where the component will be assembled. After fixing the parts to the jaw, the tool by means of the cylinders turn the circles on the key by 400 degrees. This turn results in a ring being pushed into a hole. This process produces a complete product, without the need of human intervention in assembly. When performing this part, care must be taken to ensure accuracy and rigidity. Possible inaccuracies could negatively affect serial production of products.

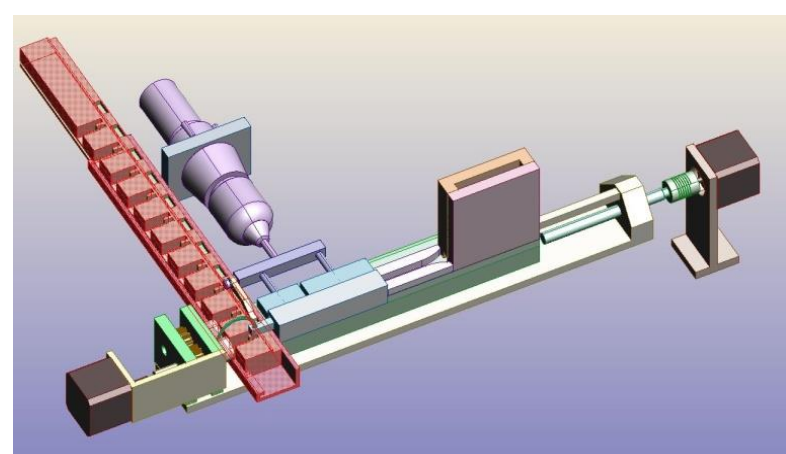

Figure 12 - The bin of the key circles

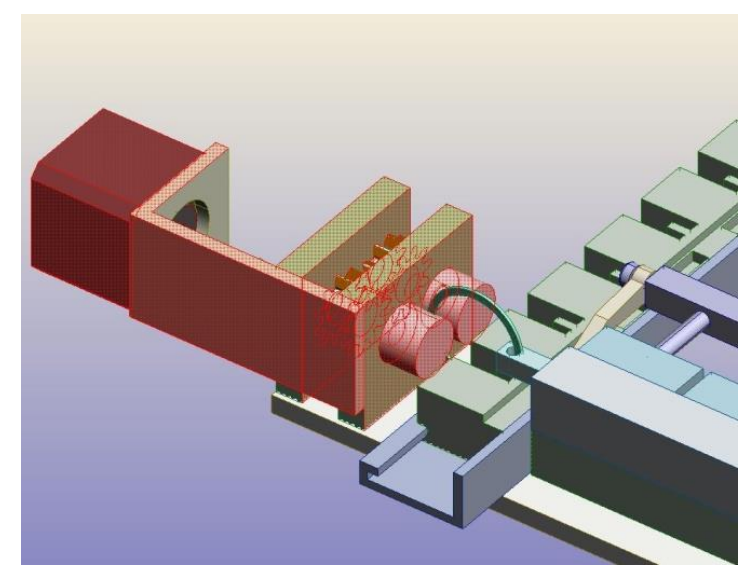

Figure 13 - Assembly of the product

\section{Realization of automation}

Drawing documentation for individual parts were created from the proposed 3D model. The parts described in the manufacturing drawings were manufactured using a conventional milling machine. Some parts have been made using a CNC milling machine. From the drawn 3D model, a machining program for the CNC milling machine was designed in the CAM software used. Aspire software was used to design the machining tool, which generated the G-code for the $\mathrm{CNC}$ equipment used to manufacture the individual parts. An example of G-code visualization is shown in Figure 14, and the implementation of the part is shown in Figure 15. After the parts were made, the individual parts were folded. By completing, we have acquired the entire structural part of the automated system.

The spindles move with a stepper motor that rotates the threaded rod. The threaded rod moves with the aid of a nut, changing the rotary motion to linear. The making of the nut houses is shown in Figure 14. In Part A, the milling simulation is shown, Part B shows the milling process to produce the complete nut housing.

We have shown the production process of the nut housing. This procedure has also been used to produce other components needed to implement automation. In the Figure 16 you can see a comparison of the 3D automation design and the real automated complete system. 


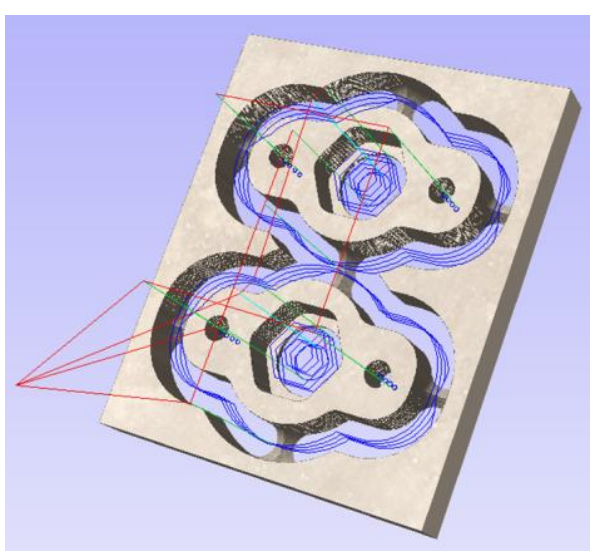

Figure 14 - Visualization of G-code (nut housing)

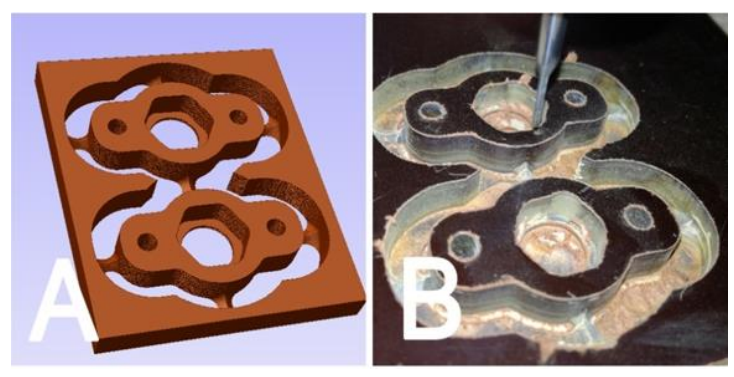

Figure 15 - The nut housing

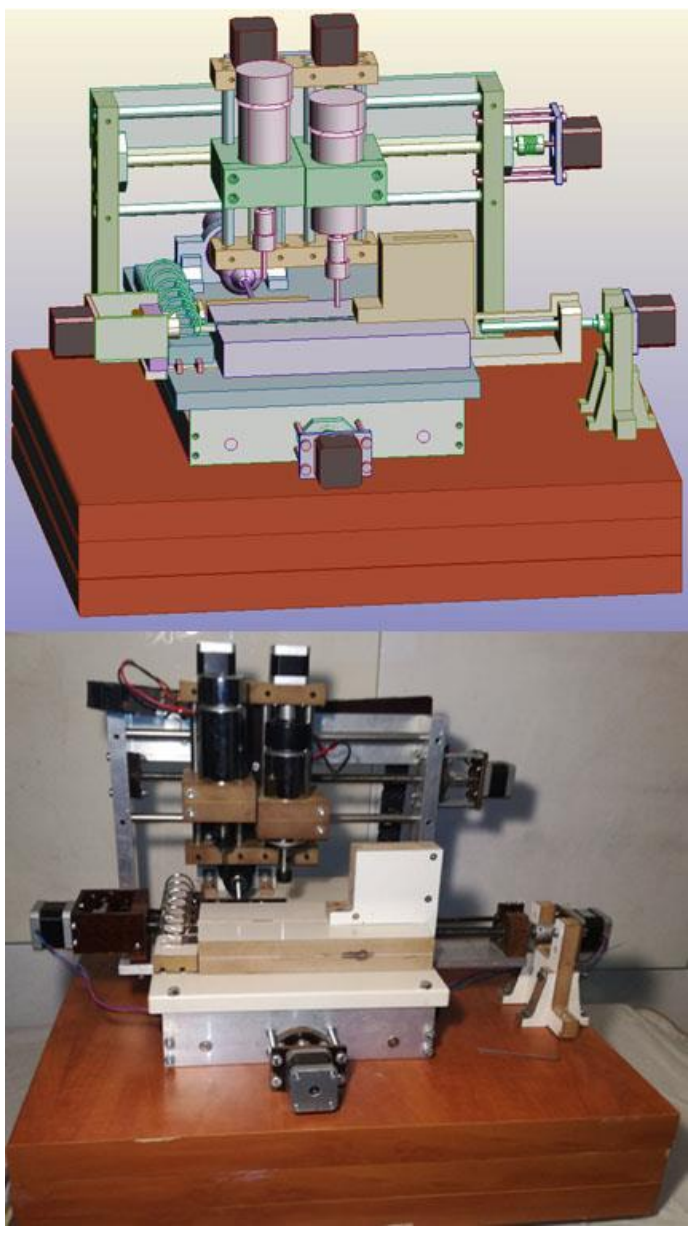

Figure 16 - The comparison of the 3D automation design and the real automated complete system
After completing the system, it needs to be set in motion. It requires the involvement of electro drivers, actuators and production calibration.

The control system of automation

To implement all of the proposed operations, it is necessary to control six stepper motors (SM) controlling the individual machine axes, two milling spindles, and another DC motor used to drive the workpiece clamping system. Each of these drives needs a control circuit and power supply. The whole system is controlled by a BeagleBone Black microcomputer. The individual relationships between the components of the electronic part of the system are shown in Figure 17 in the flowchart.

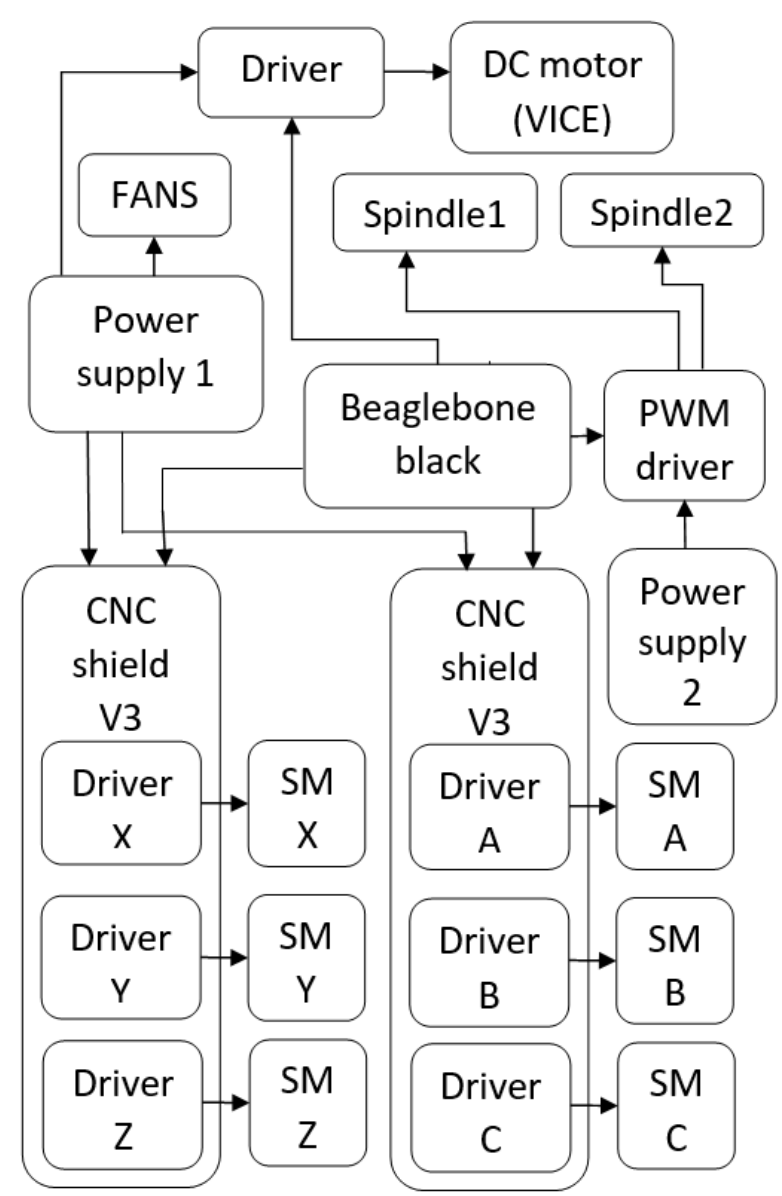

Figure 17 - The block diagram

By constructing the device design, connecting the electronic part and properly configuring the software, we created a functional system used to create automated manufacturing. CNC programming uses commands that include technological, geometric, and other auxiliary information to perform the tasks. Our system has been designed and engineered so that all its parts can be programmed in the same way as conventional CNC machines.

\section{Remote control}

Before starting to configure the system parts, we decided to implement remote access to the device for its 
more comfortable configuration. Remote access can also be used for remote control and device settings.

The task of remote access is to open the graphical interface of the Machinekit software running under Linux on BeagleBone Black hardware on a Windows computer. We use the PuTTY client and the Xming server on a Windows computer to perform the task, which communicates via the SSH protocol with the BeagleBone Black.

PuTTY - is a free Windows Telnet and SSH client. It is used for encrypted connections to a remote computer [6].

$\mathrm{SSH}$ - is a network protocol used to communicate with a remote computer [5].

Xming - is an X server for Microsoft Windows. It is installed separately, it is an extension package for PuTTY. It supports displaying the graphical interface of Linux servers in Windows [4].

Use the remote access to open the graphical software interface to make us control the system, the software features will be described as follows.

\section{Graphical user interface (GUI)}

For automated manufacturing system was chosen the Axis graphical interface. We chose it because of previous experience with the interface and its clarity. The GUI of the proposed system is shown in Figure 18, it is extension of previous GUI of CNC system.

At the top of the software there is a menu base, below the menu there are milling process controls and visualization views. The Manual Control section provides the ability to manually control the device, displaying all six configured mobile device elements. The Manual Control window contains a part of the Spindle that can control the spindle speed and select the active spindle. The recorded $\mathrm{G}$ code ready for milling is displayed at the bottom. Switching to the MDI window will allow manual entry of $\mathrm{G}$ code commands.

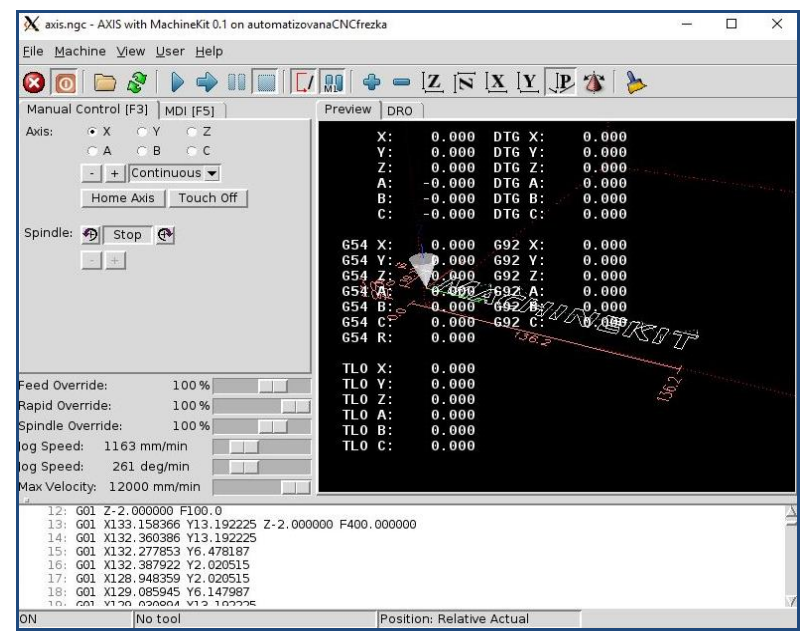

Figure $18-$ GUI of the automation

CONCLUSIONS. The production time of 5 products using an automated manufacturing system is 13 minutes and 10 seconds. The advantage of automation is to increase production speed and eliminate the need for human intervention in production, thereby increasing accuracy and eliminating the possibility of errors that a human factor could entail in the process. The disadvantage of an automated system is the complex manufacturing configuration. Therefore, such systems achieve the greatest efficiency in mass production where there is no need for frequent system setup. In Figure 19 we can see manufactured products by the automated system.

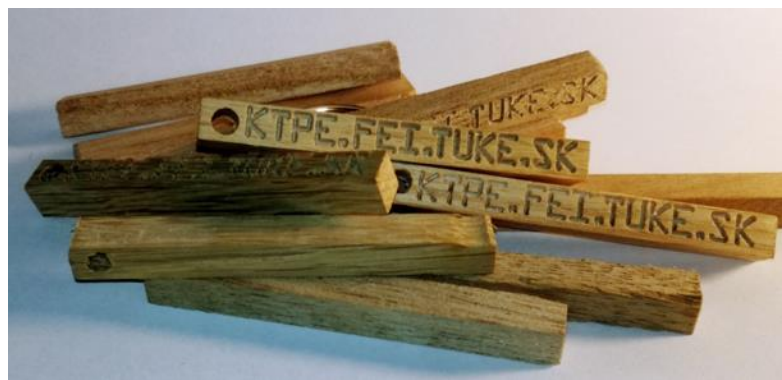

Figure 19 - Manufactured products

We determine the effectiveness of systems based on the parameters required by the system. Features such as cost-effectiveness, simple repositioning, robustness, accuracy and reliability, and many others are mutually exclusive. Therefore, when designing automated systems, it is advisable to know well the input conditions and required system characteristics, and consequently the entire implementation of the system.

\section{ACKNOWLEDGEMENT.}
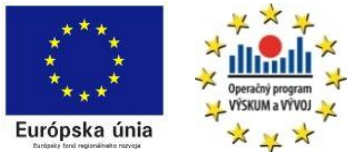

We support research activities in Slovakia / Project is co-financed

from EU funds. This paper was developed within the Project "Centre of Excellence of the Integrated Research \& Exploitation the Advanced Materials and Technologies in the Automotive Electronics ", ITMS 26220120055

\section{REFERENCES}

1. CNC router. Retrieved from https://img.staticbg.com/thumb/large/oaupload/banggoo d/images/CA/4C/10b4f5f5-4e-c5-48ed-9a29-

57ed52fd04ca.jpg

2. Chang, Chao-Hwa, \& Melkanoff, Michel A. (1989). NC machine programming and software design. Englewood Cliffs. New Jersey: Prentice-Hall.
3. Machinekit.
Retrieved

from http://www.machinekit.io/

4. Xming. Xming $\mathrm{X}$ Server. Retrieved from http://www.s-traightrunning.com/Xming

5. Searchsecurity. Secure Shell(SSH). Retrieved 
from https://searchsecurity.techtarget.com/definition/ Secure-Shell

6. Simon Tatham. PuTTY User Manual. Retrieved from https:-//the.earth.li/ sgtatham/putty/ 0.70/htmldoc/

7. Machinekit. INI Configuration. Retrieved from http://www-.machinekit.io/docs/config/ini_config/

8. User Manual V2.6.11-24-g08a2b46. Retrieved from http://linuxcnc.org/docs/2.6/pdf/
LinuxCNC_User_Manual.pdf.

9. Spilling, Torjus. (2014). Self-Improving CNC Milling Machine. Master's Thesis.

10. Hasan, MdMahedi, et al. (2019). Design and Implementation of a Microcontroller Based Low Cost Computer Numerical Control (CNC) Plotter using Motor Driver Controller. International Conference on Electrical, Computer and Communication Engineering (ECCE). IEEE, 1-5.

\section{РЕАЛИЗАЦИЯ АВТОМАТИЧЕСКОЙ РАБОТЫ ФРЕЗЕРНЫХ СТАНКОВ С ЧИСЛОВЫМ ПРОГРАММНЫМ УПРАВЛЕНИЕМ}

\section{Б. Фечко, Т. Винсе}

Технический университет Кошице

ул. Летна, 9, г. Кошице, 04200, Словакия. E-mail: branislav.fecko@tuke.sk, tibor.vince@tuke.sk

В работе представлено разработку подходов к созданию модульного принципа создания автоматизированных машинных систем, используемых для систем с числовым программным управлением для повышения эффективности производства благодаря автоматизации изменения заготовки, смены инструмента обработки и сборки продукта. Приведены результаты исследования по разработке прототипа недорогой фрезеровочной машины с числовым управлением на основе модульного принципа. Предложено одну из возможностей разработки фрезеровочной машины с числовым программным управлением с использованием недорогой платы разработчика BeagleBone Black. Авторами представлен весь процесс разработки, начиная от компьютерного моделирования разрабатываемого устройства, проектирование аппаратного обеспечения, выбора и расчета силовых преобразовательных элементов, создание аппаратного обеспечения, проектирование и разработка программного обеспечения нижнего и верхнего уровней, а также экспериментальная проверка полученных результатов. Подтверждена эффективность работы системы на основе выдвинутых требований. Такие факторы, как стоимостная эффективность, простота перемонтирование, робастность, точность и надежность, и многие другие, являются уникальными для данной разработки. Таким образом, при разработке автоматизированной системы целесообразно знать точные исходные условия и желаемые характеристики системы. Преимуществами автоматизации является повышение скорости производства и исключения участия человека в процессе производства, таким образом, повышение точности и исключения возможности внесения ошибок вследствие человеческого фактора. Недостатком автоматизированной системы является сложность конфигурирования производственного процесса. Таким образом, подобные системы достигают наибольшей эффективности при массовом производстве, когда отсутствует необходимость постоянного изменения конфигурации системы.

Ключевые слова: машина с числовым управлением, автоматизация, оси, BeagleBone Black, Machinekit. 